\title{
PENGUATAN PENDIDIKAN KARAKTER PADA PEMBELAJARAN DARING DI SMA KRISTEN 1 TOMOHON
}

\author{
YANI PIETER PITOY \\ SMA Kristen 1 Tomohon, Sulawesi Utara \\ Coresponding Autor: pieter73@ymail.com
}

\begin{abstract}
Abstrak: Penelitian ini bertujuan untuk melihat bagaimana penguatan pendidikan karakter diimplementasikan dalam LMS Edmodo serta meneliti bagaimana implementasi ini berdampak pada kehidupan peserta didik SMA Kristen 1 Tomohon. Penelitian ini menggunaan metode kuantitatif dengan teknik pengumpulan data melalui survei online dan wawancara. Hasil penelitian menunjukkan bahwa: (1) Penguatan Pendidikan Karakter dalam pembelajaran daring tetap dapat dilakukan dengan memanfaatkan Learning Management System. Implementasinya dapat dilakukan dengan memberikan pesan teks/gambar yang memuat pesan-pesan reliogitas atau pesan moral; (2) sebanyak 86\% dari responden mengakui bahwa ada tindakan/perilaku yang diinspirasi dari pesan-pesan yang dikirimkan lewat LMS Edmodo;(3) pesan-pesan moral/reliogitas dalam bentuk gambar lebih disukai daripada hanya berbentuk teks; (4) semua responden memandang penting/sangat penting pesan-pesan bernuansa reliogitas/moral disampaikan dalam kegiatan pembelajaran.
\end{abstract}

Kata Kunci: karakter, pembelajaran daring

\section{A. PENDAHULUAN}

Pandemi Corona Virus Disease 2019 (Covid-19) yang mulai terdeteksi di Indonesia awal Maret 2020 membuat Pemerintah Republik Indonesia mengambil langkah-langkah strategis untuk menghadapinya. Kementerian Pendidikan dan Kebudayaan (Kemdikbud) melalui Surat Edaran Nomor 4 Tahun 2020 memastikan kegiatan belajar mengajar di rumah dialihkan dengan kegiatan pembelajaran daring/jarak jauh. Beberapa keputusan/surat edaran yang dikeluarkan kemudian menegaskan tentang hal-hal teknis terkait kegiatan pembelajaran daring/jarak jauh.

Penguatan Pendidikan Karakter merupakan bagian integral dari implementasi pembelajaran daring/jarak jauh yang tetap harus diimplementasikan. Membangun karakter Generasi Emas 2045 tidak boleh dilupakan saat pembelajaran daring/jarak jauh. Pembelajaran daring/jarak jauh dengan basis Learning Manajemen System (LMS) saat ini banyak diterapkan di sekolah-sekolah. Penggunaan LMS memungkinkan adanya interaksi yang semakin terstruktur antara guru dan peserta didik, sehingga pembelajaran dapat dikondisikan menyerupai keadaan pembelajaran tatap muka. Hal ini tentunya tidak sepenuhnya terjadi, tetapi paling tidak dapat disesuaikan.

Peraturan Presiden Nomor 87 Tahun 2017 tentang Penguatan Pendidikan Karakter (PPK) mengamanatkan dengan jelas tanggung jawab satuan pendidikan (sekolah) untuk menguatkan karakter peserta didik melalui kegiatan harmonisasi olah hati, olah rasa, olah pikir dan olah raga. Pasal 2 Peraturan Presiden ini menyatakan 
salah satu tujuan PPK adalah untuk mengembangkan platform pendidikan nasional yang meletakkan pendidikan karakter sebagai jiwa utama dalam penyelenggaraan pendidikan bagi Peserta Didik. Hal ini ditegaskan dalam Surat Edaran Kementerian Pendidikan dan Kebudayaan Nomor 15 Tahun 2020 tentang bagaimana guru memfasilitasi pelaksanaan PJJ secara daring/luring/kombinasi keduanya.

Dalam menyiapkan pembelajaran guru diwajibkan antara lain memfokuskan pada kegiatan spiritual keagamaan serta penguatan karakter dan budaya. Hasil penelitian dari Suryanti (2018) menunjukkan bahwa program/kegiatan penguatan pendidikan karakter berbasis religius dapat meningkatkan mutu sekolah. Hal itu dimulai dengan melakukan kegiatan pembiasaan.

Moore, Dickson-Deane \& Galyen (2011), sebagaimana dikutip oleh Sadikin (2020), mengungkapkan bahwa pembelajaran daring sebagai pembelajaran yang memanfaatkan jaringan internet dengan aksesibilitas, konektivitas, fleksibilitan dan kemampuan untuk memunculkan/menghasilkan macam-macam interaksi pembelajaran. Korucu \& Alkan (2011), sebagaimana dikutip oleh Sadikin (2020) menyatakan adanya sumbangan yang besar bagi dunia pendidikan terkait penggunaan teknologi mobile, termasuk didalamnya untuk mencapai tujuan pembelajaran jarak jauh.

Berdasarkan hal-hal di atas, maka penguatan pendidikan karakter harus tetap menjadi bagian integral dari proses pembelajaran daring. Sarwono (2005:92) menyatakan bahwa dalam usia remaja mereka (peserta didik), moral merupakan sebuah kebutuhan tersendiri. Mereka sedang dalam keadaan membutuhkan pedoman atau petunjuk dalam mencari jalannya sendiri. Keterlibatan orang tua dalam penguatan pendidikan karakter memang dibutuhkan, tetapi hasil penelitian dari Aji (2020) menyatakan bahwa $92,1 \%$ orang tua tidak dapat membangun karakter anak dengan maksimal tanpa keterlibatan para guru. Sebanyak $88,2 \%$ responden menyatakan bahwa karakter peserta didik tidak dapat dibangun di rumah dan lingkungan peserta didik tanpa keterlibatan sekolah. Penelitian itu juga mengungkapkan bahwa peran serta guru dalam membangun karakter/moral peserta didik masih sangat dibutuhkan.

\section{B. METODE PENELITIAN}

Penelitian ini dilakukan untuk melihat bagaimana penguatan pendidikan karakter diimplementasikan dalam Learning Management System/LMS Edmodo. Secara khusus pula, penelitian ini akan meneliti bagaimana implementasi ini berdampak pada kehidupan peserta didik SMA Kristen 1 Tomohon.

Metode yang dipakai dalam penelitian ini adalah Metode Kuantitatif. Data diperoleh dengan metode survei dan wawancara langsung kepada peserta didik. Data dengan metode survei diperoleh dari kuisioner yang dilakukan secara online. 


\section{HASIL PENELITIAN DAN PEMBAHASAN}

Implementasi penguatan pendidikan karakter di LMS Edmodo diaplikasikan lewat fitur Post. Implementasi yang dilakukan adalah mengirim pesan berupa teks atau gambar pada awal/akhir kegiatan pembelajaran. Pesan-pesan moral yang disampaikan lebih dominan pesan kutipan ayat-ayat dari Alkitab. Sebagian lagi adalah pesan-pesan moral yang berlaku secara universal.
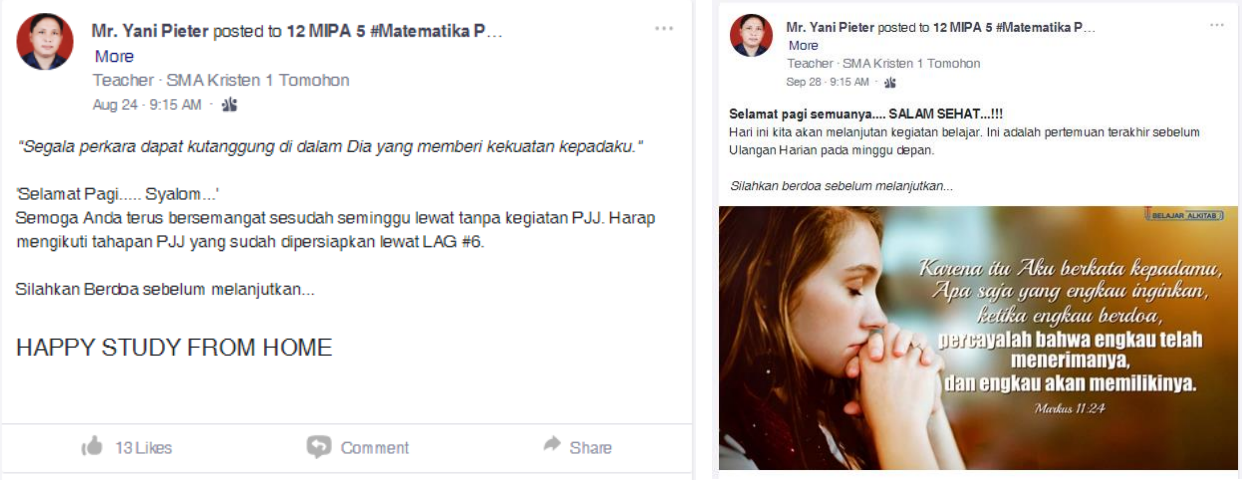

Gambar 1. Screenshot pesan Penguatan Pendidikan Karakter dalam pembelajaran daring

Informasi terkait penguatan pendidikan karakter berbasis religiositas yang disampaikan lewat LMS Edmodo (teks atau gambar) dibaca/diperhatikan oleh $82 \%$, sementara sisanya menyatakan membaca informasi tersebut 'kadang-kadang'. Terkait dengan informasi yang disampaikan ini, 83\% peserta didik menyatakan bahwa informasi tersebut menjadi pemikiran/perenungan, sehingga membuat mereka tergerak untuk melakukannya. Beberapa responden bahkan menganjurkan untuk menambah kuantitas pesan-pesan penguatan karakter berbasis religiositas tersebut. Hal ini menunjukkan bahwa mendapatkan pedoman/petunjuk dalam mencari jalannya sendiri menjadi kebutuhan mereka, sebagaimana dinyatakan oleh Sarwono (2005:93)

Pesan penguatan karakter berbasis religiositas yang disampaikan dengan latar belakang gambar ternyata lebih menarik (89\%) dibandingkan dengan tanpa gambar(teks). Hal ini mengkonfirmasi pernyataan Hartanto (2010) bahwa memang otak manusia itu lebih suka dengan sesuatu yang bergambar dan warna. Gambar bisa memiliki sejuta arti, sementara warna akan membuat segala sesuatu lebih hidup.

Penelitian ini menunjukkan bahwa ada 169 peserta didik atau $86 \%$ dari responen yang mempraktekkan informasi yang diperoleh tersebut dalam bentuk tindakan nyata. Tindakan nyata antara lain berupa penguatan secara moril untuk melaksanakan tugas sebagai peserta didik. Beberapa tindakan konkrit seperti karakter jujur dan disiplin juga terinspirasi dari pesan-pesan reliogitas/moral yang disampaikan pada saat memulai/mengakhiri pelajaran. Disisi lain, kehidupan religius juga terkoreksi dengan adanya pesan-pesan tersebut. Ali (2004:16) menyatakan bahwa remaja (termasuk peserta didik didalamnya) sebagai individu sesungguhnya memiliki dorongan alamiah untuk mengembangkan potensi yang dimilikinya. Hal ini mengindikasikan bahwa 
ketika peserta didik sebagai remaja diberi sebuah pesan yang menantang untuk dilakukan, maka secara alamiah akan ada dorongan untuk menindaklanjutinya. Beberapa hasil wawancara menunjukkan bahwa dalam pembelajaran daring, faktor jenuh sering kali muncul. Tetapi, dengan adanya pesan-pesan moral yang diberikan diawal pembelajaran daring, semangat untuk belajar kembali ada. Hal ini sejalan dengan salah satu kiat yang dianjurkan oleh Syah (2003:181) dalam mengatasi keletihan mental dari peserta didik yaitu guru memberikan motivasi dan stimulasi baru sehingga siswa terdorong untuk belajar lebih giat daripada sebelumnya.

Seberapa penting penguatan pendidikan karakter dilakukan dalam pembelajaran daring? Hasil penelitian menunjukkan bahwa semua responden menyatakan bahwa hal tersebut penting di lakukan. Bahkan $73 \%$ peserta didik menyatakan hal ini sangat penting untuk dilakukan di pembelajaran daring ini dan diharapkan akan dilakukan secara merata pada semua jenis mata pelajaran. Dalam banyak hal pesan-pesan religius sebenarnya telah mereka dapatkan dalam kegiatan-kegiatan religius (ibadah-ibadah) yang banyak dilakukan di lingkungan tempat tinggal, ataupun juga didapatkan dari sumber-sumber lain yang banyak bertebaran di internet. Penting atau bahkan sangat penting mendapatkan penguatan dalam kegiatan pembelajaran daring dalam hal moral/karakter berkaitan erat dengan percobaan Skinner sebagaima dikutip oleh Syah (2003:99). Salah satu kesimpulan dari percobaan Skinner ini adalah bahwa fenomena tingkah laku belajar peserta didik melibatkan reinforcement/penguatan. Ini berarti, jika reinforcement itu terus dilakukan, maka akan berkontribusi positif pada penguatan pendidikan karakter.

\section{KESIMPULAN}

1. Penguatan Pendidikan Karakter dalam pembelajaran daring tetap dapat dilakukan dengan memanfaatkan Learning Management System. Implementasinya dapat dilakukan dengan memberikan pesan teks/gambar yang memuat pesan-pesan reliogitas atau pesan moral.

2. Sebanyak $86 \%$ dari responden mengakui bahwa ada tindakan/perilaku yang diinspirasi dari pesan-pesan yang dikirimkan lewat LMS Edmodo.

3. Pesan-pesan moral/reliogitas dalam bentuk gambar lebih disukai daripada hanya berbentuk teks.

4. Semua responden memandang penting/sangat penting pesan-pesan bernuansa reliogitas/moral disampaikan dalam kegiatan pembelajaran. 


\section{DAFTAR PUSTAKA}

Aji, Takhroji., "Pendidikan Karakter di Masa Pandemi, Menjadi Tanggung Jawab Siapa?".

( https://bdkjakarta.kemenag.go.id/berita/pendidikan-karakter-di-masapandemi-menjadi-tanggung-jawab-siapa) (Diakses 1 Oktober 2020)

Ali, Mohammad dan Mohammad Asroni., "Psikologi Remaja: Perkembangan Peserta Didik". Jakarta: PT Bumi Aksara. 2004

Hadi, Sutrisno., "Metodologi Riset". Yogyakarta: Pustaka Belajar. 2015

Sadikin, Ali dan Afreni Hamidah.,"Pembelajaran Daring di Tengah Wabah Covid-19".

( https://www.online-journal.unja.ac.id/biodik/article/view/9759) (Diakses 1

Oktober 2020)

Peraturan Presiden Republik Indonesia Nomor 87 Tahun 2017 Tentang Penguatan Pendidikan Karakter

Sarwono, Sarlito Wirawan., "Psikologi Remaja". Jakarta: PT. RajaGrafindo Persada. 2005

Sugiyono., "Metode Penelitian \& Pengembangan Untuk Bidang: Pendidikan, Manajemen, Sosial, Teknik". Bandung: Penerbit Alfabeta Bandung. 2015

Suhadisiwi, Indarti. "Panduan Praktis Implementasi Pendidikan Karakter (PPK) Berbasis Budaya Sekolah". Jakarta: Pusat Analisis dan Sinkronisasi Kebijakan (PASKA). 2018

Surat Edaran Nomor 15 Tahun 2020 Tentang Pedoman Penyelenggaraan Belajar Dari Rumah Dalam Masa Darurat Penyebaran Corona Virus Disease (Covid-19).

Syah, Muhibbin., "Psikologi Belajar". Jakarta: PT. RajaGrafindo Persada. 2005 .,"Kebijakan Penguatan Karakter".

(https://cerdasberkarakter.kemdikbud.go.id/?page_id=132) (Diakses 30 September 2020)

,"Otak Lebih Suka Gambar dan Warna".

(https://health.detik.com/berita-detikhealth/d-1404800/otak-lebih-suka-gambardan-warna) (Diakses 1 Oktober 2020) 